\title{
Rekam Jejak dan Tantangan Riset Dosen Vokasi Otomotif di Indonesia: Screening dari Google Scholar 2016-2018
}

\section{Track Record and Research Challenges of Automotive Vocational Lecturer in Indonesia: Screening from Google Scholar 2016-2018}

\author{
Bagiyo Condro Purnomo1, Muhammad Latifur Rochman², Muji Setiyo ${ }^{1,2 *}$ \\ ${ }^{1}$ Program Studi Mesin Otomotif Universitas Muhammadiyah Magelang \\ Jl. Bambang Sugeng km.05 Mertoyudan Magelang \\ ${ }^{2}$ Laboratorium Otomotif Universitas Muhammadiyah Magelang \\ Jl. Bambang Sugeng km.05 Mertoyudan Magelang
}

doi.10.21063/JTM.2019.v9i1.18-27

*Correspondence should be addressed to setiyo.muji@ummgl.ac.id

Copyright (C) 2019 B. C. Purnomo. This is an open access article distributed under the CC BY-NC-SA 4.0.

\begin{abstract}
Article Information
Abstract

Submitted :

March 7, 2019

Accepted :

April 18, 2019

Published :

April 30, 2019

This article presents a research review of automotive vocational lecturers in Indonesia obtained from google scholar during 2016-2018. We found more than 500 articles on google scholar produced by 277 lecturers from automotive vocational programs. However, through data filtering, there are only 208 publications related to automotive, including the development of learning media in VHE. Looking at the world automotive research trend (which leads to major issues regarding battery systems, downsizing and turbocharging, and advanced combustion modes), and with concerns about the availability of fossil energy, major and fundamental reforms are needed for research activities in automotive vocational lecturers in Indonesia, both in terms of topic and depth of research material. As a recommendation, stakeholders in automotive vocational programs in universities should immediately form a research roadmap together and form a national automotive research consortium in order to contribute in realizing environmentally friendly vehicle technology and a sustainable national transportation system.
\end{abstract}

Keywords: Research trend, Vocational automotive lecturer, Google scholar

\section{Pendahuluan}

Teknik otomotif adalah cabang ilmu terapan dari ilmu mekanikal secara umum, yang berkaitan dengan merancang, mengembangkan, dan memproduksi kendaraan darat untuk kendaraan penumpang dan niaga maupun jenis kendaraan khusus untuk kepentingan pertambangan, pertahanan, industri, kompetisi, dan sebagainya. Dalam pengembangan kendaraan baru, kriteria desain utama harus memperhatikan konsumsi bahan bakar, keselamatan kendaraan, kelayakan tabrakan, daya tahan, kenyamanan berkendara, ergonomi, aerodinamika, dan konsep Noise, Vibration, and Harshness (NVH). Oleh karena itu, industri otomotif harus mampu membuat keputusan penting di antara parameter desain ini [1].

Lembaga-lembaga riset otomotif dituntut untuk melakukan penelitian multidisiplin yang mencakup analisis, pemodelan, eksperimen dan pengujian laboratorium. Kegiatan tersebut harus didukung dengan fasilitas penelitian yang canggih, tim ilmuwan dan insinyur multidisiplin yang saling bersinergi. Hampir semua lembaga riset otomotif sedang berupaya memecahkan tantangan besar dan kecil yang terkait dengan pengembangan desain drivetrain kendaraan yang lebih baik, material baru, bahan bakar yang lebih baik, dan proses yang lebih baik untuk mendukung transisi teknologi transportasi 
menuju lingkungan yang lebih bersih dan lebih berkelanjutan [2].

Meskipun target kendaraan masa depan adalah berbasis propulsi listrik, namun untuk saat ini transportasi masih tergantung pada bahan bakar fosil [3]. Pada 2016, bensin dan solar/diesel berkontribusi $92 \%$ dari total energi yang digunakan dalam transportasi. Konsumsi energi di sektor transportasi tidak hanya menimbulkan kekhawatiran tentang keamanan energi dan efek gas rumah kaca tetapi juga menyebabkan penurunan kualitas udara terutama di kota-kota besar yang berdampak pada kesehatan manusia [4].

Untuk transportasi berkelanjutan dan pengurangan emisi $\mathrm{CO}_{2}$, penggunaan bahan bakar alternatif, kendaraan listrik dan hybrid terus dipromosikan [5]. Produksi dan penjualan kendaraan berbahan bakar fosil direncanakan akan dihapus dalam waktu dekat. Issu ini akan dijadikan target serius seperti di Norwegia, Prancis, Inggris dan beberapa negara maju lainnya [6], [7]. Oleh karena itu, model kebijakan dan strategi untuk penerapan bahan bakar alternatif dan sistem propulsi listrik telah disimulasikan dan diuji-terapkan untuk mencapai titik manfaat yang terbesar dengan resiko yang lebih kecil [8]-[10].

Bagaimana roadmap pengembangan kendaraan bersih di Indonesia? Pada tahun 2013, Pemerintah mengeluarkan peraturan tentang produksi kendaraan Low Cost Green Car (LCGC) [11], yang kemudian akan disusul dengan program Low Carbon Emission Program (LCEP) [12]. Dalam Energy Mix 2025, berbagai jenis bahan bakar alternatif selain bensin dan solar telah ditargetkan untuk dipakai di sektor transportasi [13]. Pemerintah juga berencana mengimplementasikan kendaraan berbasis propulsi listrik untuk masa mendatang, dengan target 20\% di tahun 2025, seperti yang dirilis oleh Republika [14].

Melihat kondisi tersebut, perguruan tinggi yang menyelenggarakan program diploma otomotif harus menyesuaikan topik riset yang memungkinkan untuk menghasilkan produk riset yang mendukung perkembangan otomotif nasional. Pengintegrasian riset kedalam pembelajaran juga mutlak diperlukan agar lulusannya memiliki tingkat penerimaan yang lebih besar di industri otomotif. Oleh karena itu, artikel ini menyajikan sebuah review terhadap trend riset yang dilakukan oleh dosen dan mahasiswa vokasi otomotif selama periode 2016 sampai 2018 yang diperoleh dari google scholar. Kemudian, peta riset tersebut dibandingkan dengan trend pengembangan teknologi otomotif sebagai evaluasi dan untuk membuat sebuah opini saintifik.

\section{Metode}

Dalam studi ini, data dosen vokasi otomotif diperoleh dari Pangkalan Data Perguruan Tinggi (https://forlap.ristekdikti.go.id/) untuk program D3 dan D4. Kemudian, publikasi setiap dosen dengan yang ber-homebase di program studi tersebut ditelusuri di google scholar. Selanjutnya, data ditabulasi dengan MS Excel untuk memastikan tidak ada publikasi yang terduplikasi karena terklaim pada list publikasi beberapa dosen. Data tersebut kemudian diklasifikasi, hanya publikasi artikel yang terkait dengan bidang otomotif saja yang diambil. Terakhir, data yang sudah terfilter tersebut diklasifikasikan berdasarkan bidang risetnya. Keseluruhan pekerjaan untuk mendapatkan data disajikan dalam Gambar 1 sebagai berikut.

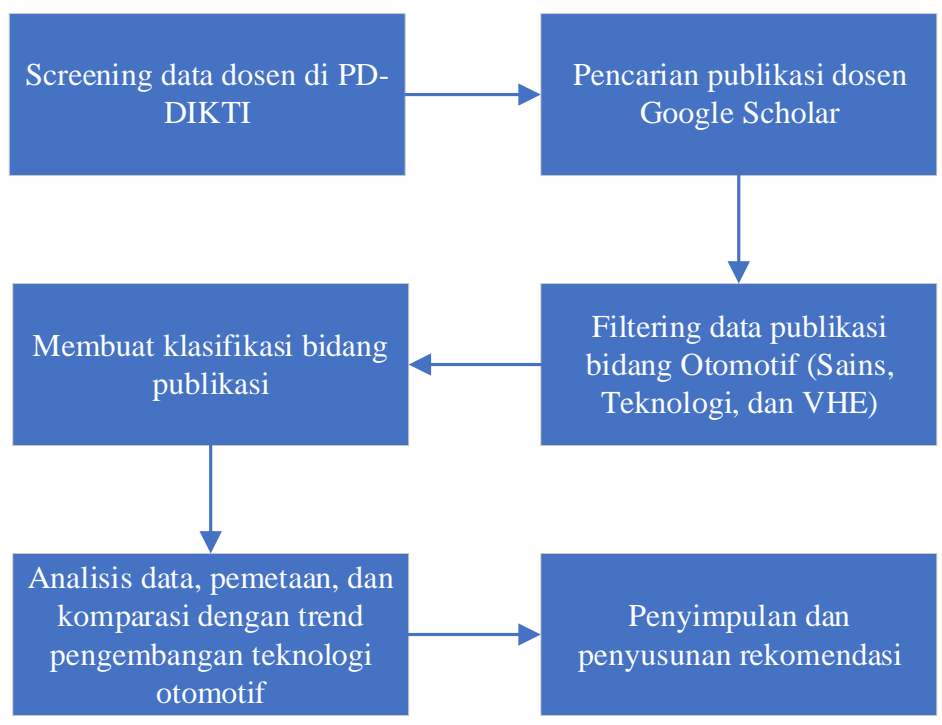

Gambar 1. Tahapan penelitian 


\section{Hasil dan Pembahasan}

\section{A. Produktifitas dan Sebaran Riset}

Berdasar data di PDPT untuk pelaporan 2018/2019, kami menemukan ada 186 dosen D3 dan 91 dosen D4 yang ber-homebase di program studi otomotif dengan status aktif. Namun demikian, dari 277 dosen tersebut belum seluruhnya memiliki akun di google scholar sehingga data publikasi dosen tersebut tidak diperhitungkan dalam analisis ini. Selanjutnya, dari dosen-dosen yang terdaftar di google scholar, ditemukan lebih dari 500 publikasi dalam 3 tahun terakhir (2016-2018). Dari jumlah tersebut, kemudian dilakukan filterisasi dan hanya publikasi yang berkaitan dengan otomotif saja yang dimasukkan dalam analisis, dengan jumlah 208 artikel. Jumlah tersebut termasuk artikel Tugas Akhir yang dipublikasikan mahasiswa bersama dosen pembimbing.

Dari pengamatan yang kami lakukan, tidak semua dosen yang ber-homebase di otomotif memiliki rekam jejak publikasi tentang otomotif karena berbagai alasan, namun yang mendominasi adalah latar belakang pendidikan. Selain memang ada dosen yang sama sekali tidak memiliki latar belakang pendidikan keteknikan namun ditugaskan di program studi tersebut. Sebagai contoh, dosen dengan latar belakang Magister Pendidikan akan cenderung melakukan riset-riset tentang kependidikan. Demikian pula, dosen dengan latar belakang pendidikan teknik mesin (material) juga akan melakukan riset tentang material yang kadang sangat sulit untuk dihubungkan dengan otomotif. Selain itu, banyak juga ditemui artikel hasil pengabdian masyarakat, buku, dan modul yang masuk dalam daftar google scholar masing-masing dosen. Profil publikasi dosen vokasi otomotif selama tahun 2016-2018 berdasarkan pemeringkatan dan sebaran pertahun disajikan dalam Gambar 2 dan Gambar 3 secara berurutan.

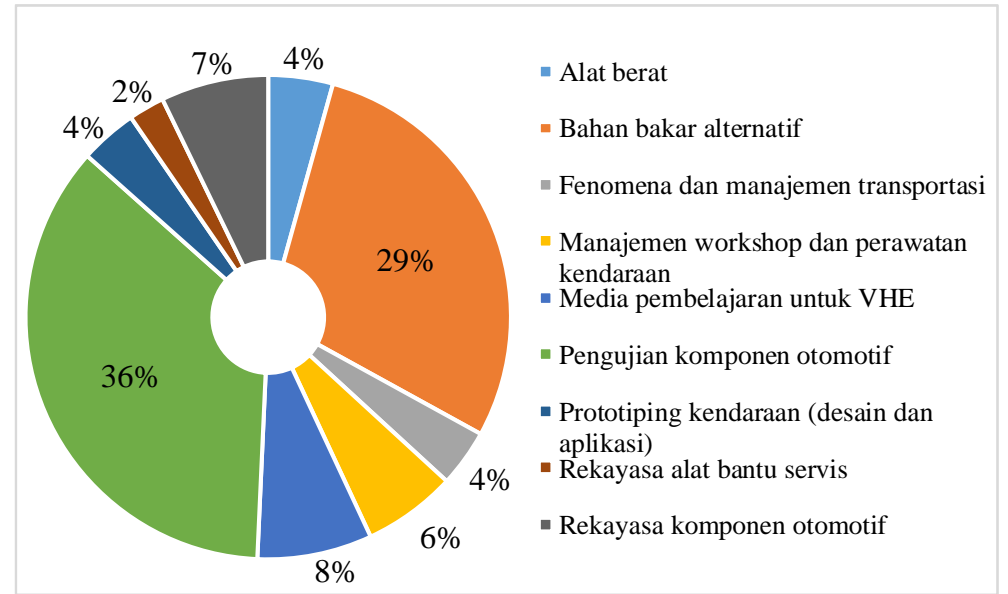

Gambar 2. Peringkat publikasi dosen vokasi otomotif tahun 2016-2018 di google scholar

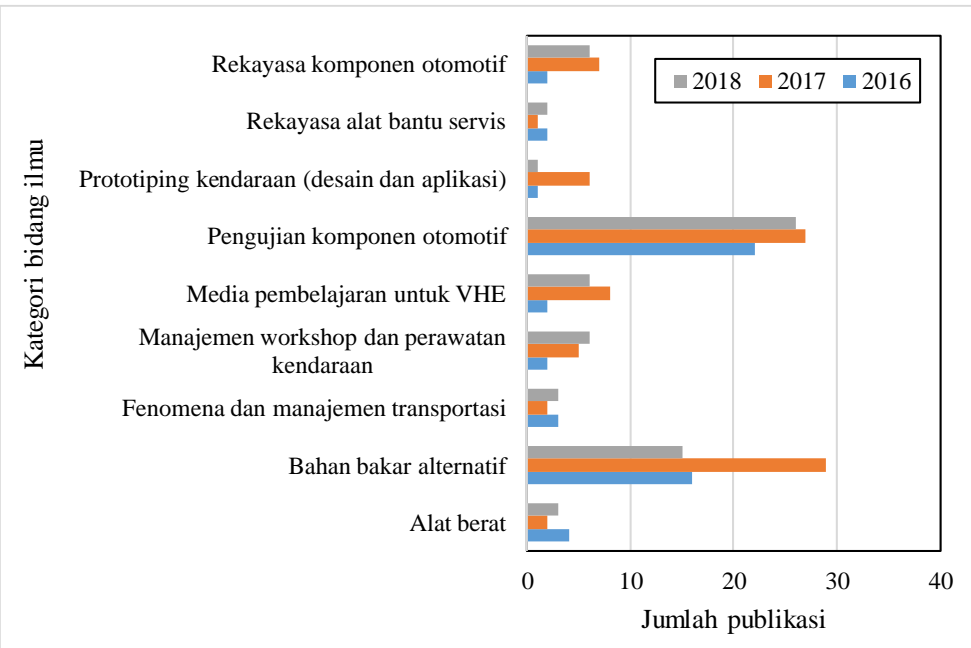

Gambar 3. Data publikasi dosen vokasi otomotif tahun 2016-2018 di google scholar 
Dari Gambar 2, diperoleh informasi bahwa peringkat tertinggi topik-topik riset dosen vokasi otomotif adalah bidang pengujian komponen mesin, disusul dengan ujicoba bahan bakar alternatif. Dibawah dua topik tersebut ada topik riset tentang media pembelajaran $(8 \%)$ dan rekayasa komponen otomotif (7\%). Kemudian dari Gambar 3, sebuah asumsi dapat diambil bahwa trend riset selama 3 tahun terakhir memiliki kesamaan bidang riset. Oleh karena itu, analisis lebih detail tentang topiktopik riset yang dilakukan dosen vokasi otomotif dilakukan untuk tahun 2018 saja, yang mewakili trend riset terkini, sebagaimana disajikan dalam Tabel 1.

Tabel 1. Trend riset dosen vokasi otomotif tahun 2018

\begin{tabular}{|c|c|c|c|}
\hline No & Bidang & Sub-bidang/ topik riset & Referensi \\
\hline 1 & Alat berat & Perawatan alat berat & {$[15]-[17]$} \\
\hline \multirow[t]{5}{*}{2} & \multirow{5}{*}{ Bahan bakar alternatif } & Biodiesel & [18], [19] \\
\hline & & $\mathrm{CNG}$ & [20] \\
\hline & & Ethanol & {$[21]-[28]$} \\
\hline & & Hydrogen & [29], [30] \\
\hline & & LPG & [31], [32] \\
\hline \multirow[t]{2}{*}{3} & \multirow{2}{*}{$\begin{array}{l}\text { Fenomena dan manajemen } \\
\text { transportasi }\end{array}$} & Efisiensi bahan bakar & [33] \\
\hline & & Polusi & {$[34],[35]$} \\
\hline \multirow[t]{2}{*}{4} & \multirow{2}{*}{$\begin{array}{l}\text { Manajemen workshop dan } \\
\text { perawatan kendaraan }\end{array}$} & Efisiensi biaya & {$[36]-[39]$} \\
\hline & & $\begin{array}{l}\text { Kompetensi dan keselamatan } \\
\text { kerja }\end{array}$ & [40], [41] \\
\hline 5 & $\begin{array}{l}\text { Media pembelajaran untuk } \\
\text { VHE }\end{array}$ & $\begin{array}{l}\text { Pengembangan media } \\
\text { pembelajaran }\end{array}$ & {$[42]-[47]$} \\
\hline \multirow[t]{4}{*}{6} & \multirow{4}{*}{$\begin{array}{l}\text { Pengujian komponen } \\
\text { otomotif }\end{array}$} & Pengujian komponen mesin & {$[48]-[55]$} \\
\hline & & Emisi & {$[56]-[63]$} \\
\hline & & Performa mesin & {$[64]-[69]$} \\
\hline & & Konsumsi bahan bakar & {$[70]-[72]$} \\
\hline 7 & Prototiping kendaraan & Desain dan uji terap & [73] \\
\hline 8 & Rekayasa alat & Pengembangan alat bantu servis & {$[74],[75]$} \\
\hline \multirow[t]{4}{*}{9} & \multirow{4}{*}{$\begin{array}{l}\text { Rekayasa komponen } \\
\text { otomotif }\end{array}$} & Material maju & [76] \\
\hline & & $\begin{array}{l}\text { Asesories dan pendukung } \\
\text { keselamatan kendaraan }\end{array}$ & [77], [78] \\
\hline & & Modifikasi komponen & {$[79]$} \\
\hline & & HVAC & {$[80],[81]$} \\
\hline
\end{tabular}

\section{B. Tantangan Riset Dosen Vokasi Otomotif}

Pada tahun 2013, The American Society of Mechanical Engineers (ASME) merilis artikel tentang "3 Emerging Trends in Automotive Engineering", dengan issu utama battery system, downsizing and turbocharging, dan advanced combustion modes [82]. Kemudian, "Emerging Trends in Automotive Engineering" juga menjadi topik utama dalam " 6 th International Conference and Exhibition on Automobile \& Mechanical Engineering" yang diselenggarakan oleh OMIC International di Zurich pada pertengahan tahun 2019 [83]. Topik yang akan dijadikan diskusi utama dalam konferensi itu meliputi: battery systems, wireless charging system, new energy cars, personalized driving system, uses of lightweight and cost-effective materials, autonomous driving, vehicle connectivity, engine efficiency, advanced combustion modes, fuel cells, dan downsizing and turbocharging.
Argone National Laboratory (ANL) juga sedang bekerja kearah yang sama, meskipun dengan area riset yang sedikit berbeda. Para peneliti di ANL sedang bekerja keras untuk mencapai nilai efisiensi dalam bidang teknologi pembakaran; ekonomi dan infrastruktur; forecasting, pemetaan, dan pemodelan energi; teknologi mesin; teknologi bahan bakar; teknologi grid system; life-cycle; simulasi transportasi; kendaraan listrik; material untuk otomotif; dan analisis performa kendaraan [84].

Dengan melihat data riset dosen vokasi otomotif pada Tabel 1 dan membandingkannya dengan trend otomotif dunia, perlu upaya dan kerja keras dari pengelola program studi untuk menyediakan fasilitas riset yang memadai. Namun, penyediaan fasilitas secara mandiri dalam waktu dekat sepertinya sulit terwujud karena melibatkan biaya yang besar. Sebagai alternatif solusinya, perlu untuk dibuat konsorsium riset otomotif nasional, yang 
melibatkan dosen otomotif di perguruan tinggi, industri otomotif, dan pemerintah. Dengan demikian, akan ada sharing sumberdaya (peneliti, fasilitas, biaya) untuk mewujudkan teknologi kendaraan yang ramah lingkungan dan sistem transportasi nasional yang berkelanjutan.

Pengelola program studi otomotif juga perlu untuk berkumpul dan berdiskusi membuat roadmap riset secara bersama yang mengarah pada Emerging Trends in Automotive Engineering untuk mengejar ketertinggalan penguasaan teknologi. Dengan banyaknya topik riset yang perlu dikerjakan, ini juga sekaligus dapat dijadikan pintu masuk untuk mencapai keunggulan dan kekhasan riset di masingmasing perguruan tinggi. Sebagai contoh, perguruan tinggi A memiliki roadmap untuk mencapai keunggulan dalam bidang fuel cell, perguruan tinggi $\mathrm{B}$ dibidang driving mode, perguruan tinggi $\mathrm{C}$ di material, dan sebagainya.

\section{Simpulan}

Melihat trend perkembangan riset otomotif dunia, dan dengan pertimbangan kekhawatiran tentang ketersediaan energi fosil, nampaknya perlu sebuah perubahan besar dan mendasar terhadap pola riset dosen vokasi otomotif di Indonesia. Berdasar pada trend riset selama ini, dapat menilai bahwa masih ada jarak yang cukup jauh antara capaian riset dosen vokasi otomotif dengan skema perkembangan otomotif dunia, baik dari sisi topik riset maupun dari sisi kedalaman materinya. Sebagai rekomendasi dari studi ini, para pengelola program vokasi otomotif di perguruan tinggi perlu secepatnya menyusun roadmap riset bersama dan membentuk konsorsium riset otomotif nasional untuk mewujudkan teknologi kendaraan yang ramah lingkungan dan sistem transportasi nasional yang berkelanjutan.

\section{Referensi}

[1] A. Oktav, "New Trends and Recent Developments in Automotive Engineering," in Researches on Science and Art in 21st Century Turkey, A. A. asan Arapgirlioğlu, Robert L. Elliott, Edward Turgeon, Ed. Gece Kitaplığı, 2017.

[2] Argonne National Laboratory, "Advanced Vehicle Technologies," Energy Systems. [Online]. Available: http://www.anl.gov/energysystems/group/advanced-vehicletechnologies. [Accessed: 04-Mar-2018].
[3] EIA, "Global Transportation Energy Consumption: Examination of Scenarios to 2040 using ITEDD," Washington DC, 2017.

[4] R. . Colvile, E. . Hutchinson, J. . Mindell, and R. . Warren, "The transport sector as a source of air pollution," Atmospheric Environment, vol. 35, no. 9, pp. 15371565, Mar. 2001.

[5] U. Eberle, B. M€uller, and R. von Helmolt, "Fuel cell electric vehicles and hydrogen infrastructure: status 2012," Energy \& Environmental Science, vol. 5, pp. 8780-8798, 2012.

[6] Jess Staufenberg, "Norway to 'completely ban petrol powered cars by 2025,"' Independent, 2016. [Online]. Available:

https://www.independent.co.uk/. [Accessed: 24-May-2019].

[7] Environews, "Carbon neutrality: France sets 2040 date to phase out fossil-fuelpowered vehicles," 2017. [Online]. Available:

http://www.environewsnigeria.com. [Accessed: 24-May-2019].

[8] WLPGA, Guide to new autogas markets: A step-by-step approach to introducing LPG use for transport based on lessons learned from successful markets. Neuilly-sur-Seine: WLPGA, 2018.

[9] I. C. Setiawan, "Policy Simulation of Electricity-Based Vehicle Utilization in Indonesia (Electrified Vehicle - HEV, PHEV, BEV and FCEV)," Automotive Experiences, vol. 2, no. 1, pp. 1-8, 2019.

[10] C. Clay, "Natural Gas Vehicles: Opportunities and Challenges in the Transportation Sector." Drive Natural Gas Initiative, Washington D.C., pp. 119, 2012.

[11] Peraturan Menteri Perindustrian Republik Indonesia Nomor 33/MIND/PER/7/2013 tentang Pengemabangan Produksi Kendaraan Bermotor Roda Empat yang Hemat Energi dan Harga Terjangkau. Indonesia, 2013.

[12] Gaikindo, "Indonesia Automotive Industry Report on 2013 Auto Market," in The 20th APEC Automotive Dialogue, 2014, no. April. 
[13] Kementerian ESDM Republik Indonesia, "Blueprint Pengelolaan Energi Nasional 2006-2025.” Jakarta, 2006.

[14] D. S. Saputri, "2025, Menperin Target 20 Persen Produksi Kendaraan Listrik," Republika Online, 2019. [Online]. Available: https://www.republika.co.id/. [Accessed: 24-May-2019].

[15] H. Purwono and R. Rasma, "Analisis Kebocoran Air Pendingin Dari Radiator Pada Bulldozer Tipe D375A-5," Prosiding Semnastek, 2018.

[16] V. A. T. Manurung, Y. T. Joko, and R. I. Poetra, "Auto Drain Valve Water Separator inside the Unit of Komatsu HD 465-7R," in IOP Conf. Series: Materials Science and Engineering, 2018, pp. 0-5.

[17] H. Purwono, "Perancangan Special Tool Remove And Install Hoist Cylinder Pada Unit Dump Truck HD 1500-7," in Prosiding Semnastek, 2018, pp. 1-10.

[18] I. K. Nugraheni, Triyono, W. Trisunaryanti, Nuryati, and A. Angkasa, "Physical Properties of Palm Oil Mill Effluent Trans- esterification with Local Zeolite," in AIP Conference Proceedings, 2018, no. November.

[19] Y. Yuhelson, P. Prasetya, and J. Lukman, "Test of Biodiesel Usage to Engine Performa on Dong Feng Diesel with Power 7 HP," Prosiding CELSciTech, 2018.

[20] R. M. Susanto and M. Setiyo, "Natural Gas Vehicle (NGV): Status Teknologi dan Peluang Pengembangannya," Automotive Experiences, vol. 1, no. 01, pp. 1-6, 2018.

[21] I. Yamin, B. Sugiarto, S. Abikusna, and D. Suntoro, "The use of low grade bio ethanol as fuel mixer in gasoline engine with optimization compact distillator," in E3S Web of Conferences, 2018.

[22] S. Abikusna, B. Sugiarto, and R. Monasari, "Utilization distillate low grade bioethanol as fuel mixing on SI engine (from carburetor to injection)," AIP Conference Proceedings, 2018.

[23] M. Setiyo, Saifudin, A. W. Jamin, R. Nugroho, and D. W. Karmiadji, "The Effect of Ethanol on Fuel Tank Corrosion Rate," Jurnal Teknologi, vol. 80, no. 6, pp. 19-25, 2018.
[24] B. Waluyo, I. N. G. Wardana, L. Yuliati, and M. N. Sasongko, "The role of molecule cluster on the azeotrope and boiling points of isooctane-ethanol blend," Fuel, vol. 215, no. September 2017, pp. 178-186, 2018.

[25] R. Monasari, S. Abikusna, B. Sugiarto, and B. Ajiseno, "Analysis of emission gas and fuel consumption on SI engine fueled with low-grade bioethanol and oxygenated cycloheptanol additive," in IOP Conf. Series: Earth and Environmental Science, 2018.

[26] S. Abikusna, B. Sugiarto, R. Monasari, R. Aditya, and D. Hendrawan, "Performance analysis (WHP and torque) on SI engine fueled with lowgrade bioethanol and oxygenated fuel additive," in IOP Conf. Series: Earth and Environmental Science, 2018.

[27] I. K. Nugerahen and M. M. A. Pratama, "Pengukuran Penggunaan Bahan Bakar Biofuel (Premium Dan Bioetanol) Terhadap Kinerja Mesin Bensin 4 Tak," Elemen, vol. 5, no. 1, pp. 1-6, 2018.

[28] I. Yuwono and A. C. Arifin, "Studi Eksperimen Rekayasa ECU Pada Sepeda Motor untuk Pemakaian Bahan Bakar Etanol 95 Persen," Journal of Electrical Electronic Control and Automotive Engineering (JEECAE), vol. 3, no. 2, pp. 195-198, 2018.

[29] J. Tokuda, S. Mukasa, H. Tanaka, I. Rahim, and S. Nomura, "Characteristic Of Argon Plasma Jet From Methane Hydrate Decomposition For Hydrogen Production," in International Heat Transfer Conference, 2018.

[30] Raji and Jusnita, "Hidrogen sebagai penghemat bahan bakar pada sepeda motor matic," in Simposium Nasional Teknologi Terapan (SNTT) V, 2018.

[31] M. Setiyo, B. C. Purnomo, B. Waluyo, D. R. B. Syaka, and N. Hamidi, "Refrigeration effect and energy efficiency ratio (EER) calculation of $1 / 2$ cycle refrigeration system on LPG-fueled vehicles," in IOP Conf. Series: Materials Science and Engineering, 2018.

[32] M. Setiyo, B. Waluyo, Ba. C. Purnomo, D. W. Karmiadji, and I. C. Setiawan, "Potential of $1 / 2$ cycle refrigeration system for food transport application," in IOP 
Conf. Series: Materials Science and Engineering, 2018.

[33] B. A. Prasetyo, D. A. Rizani, M. Setiyo, N. Widodo, Saifudin, and B. C. Purnomo, "Estimasi Pemborosan Bahan Bakar Akibat Kemacetan Menggunakan Analisis Citra Google Map (Studi Kasus pada Simpang Armada Town Square Mall Magelang)," Automotive Experiences, vol. 1, no. 02, pp. 36-42, 2018.

[34] I. Hasan, Erwin, A. K. Junaidi, and D. S. Arief, "Traffic Noise Impact in Perspective of City Ecology," Journal of Aeronautical, vol. 14, no. 2014, pp. 1-4, 2018.

[35] M. H. Anshari, K. D. Artika, and A. Kuswoyo, "Analisa Pengukuran Tingkat Kebisingan Sepeda Motor Berdasarkan Rpm Dan Jumlah Kendaraan," Elemen, vol. 5, no. 1, pp. 7-10, 2018.

[36] V. A. T. Manurung and K. Anam, "Menurunkan Kerusakan Yang Tidak Terjadwal (Unschedule Breakdown) Sistem Transmisi Motor Grader Komatsu Tipe GD 825A-2 Di PT Pamapersada Distric Adaro," TECHNOLOGIC, vol. 9, no. $1,2018$.

[37] V. A. T. Manurung and Setiawan, "Oil Flushing Method To Avoid Unschedule Breakdown Final Drive Components At Komatsu Dump Hd465-7r In Pt Atp," in ICETASIA, 2018.

[38] B. W. Suroto Munahar, Bagiyo Condro Purnomo, Muji Setyo, "Peningkatan Pengelolaan Unit Usaha Bengkel Kampus Dengan Penguatan Manajerial," Dianmas, vol. 7, no. 1, pp. 59-68, 2018.

[39] A. Fiatno, D. Jumali, and Misrianto, "Penerapan Realibility Centered MAintenance (RCM) pada Poros Depan Isuzu Type CXZ-51," Jurnal Teknik Industri Terintegrasi, vol. 1, no. 1, pp. 914, 2018.

[40] L. S. H. Wakhinuddin and T. Sugiarto, "Faktor-Faktor Yang Mempengaruhi Tindakan Tidak Aman Pada Mekanik Bengkel Toyota Di Kota Padang Tahun 2017," Automotive Engineering Education Journal, vol. 1, no. 1, 2018.

[41] M. A. S. Mandra, Saharuna, and H. A. Gani, "Peningkatan pengetahuan dan keterampilan penggunaan Engine
Scanner pada mekanik bengkel mobil di Kabupaten Wajo," in Prosiding Seminar Nasional Lembaga Pengabdian Kepada Masyarakat Universitas Negeri Makassar, 2018, no. 1, pp. 530-532.

[42] Tafakur and M. Solihin, "Electronic Spark Advance Ignition System Simulator As Instructional Media For Assisting Electrical Practices On Automotive Field," VANOS Journal of Mechanical Engineering Education, vol. 3, no. 1, 2018.

[43] M. Raybian Nur, "Media Pembelajaran Pelepasan Panas Menggunakan Radiator Motor Dengan Variasi Kipas Dan Kecepatan Kipas," PolhaSains, vol. 06, no. 2, pp. 2-6, 2018.

[44] W. Yahya, "Desain Media Pembelajaran Sistem Kontrol Elektropneumatik Berbasis Programmable Logic Controller," Jupiter (Jurnal Pendidikan Teknik Elektro), vol. 3, no. 1, p. 42, 2018.

[45] H. Nasrullah, "Pembuatan dan Pengujian Media Pembelajaran K3 (Keselamatan (Keselamatan dan Kesehatan Kerja) Berbasis Android," Automotive Experiences, vol. 1, no. 02, pp. 53-57, 2018.

[46] R. Syahyuniar, Y. Ningsih, and R. D. Kurniawan, "Perancangan Sistem Kerja Simulator AC (Air Conditioner) Mobil," Jurnal Elemen, vol. 5, no. 1, p. 20, 2018.

[47] I. Y. Basri, A. Arsyfadhillah, D. Irfan, and T. Thamrin, "Rancang Bangun Media Pembelajaran Mini Trainer IC 555," INVOTEK: Jurnal Inovasi Vokasional dan Teknologi, vol. 18, no. 2, pp. 65-76, 2018.

[48] W. Purwanto, T. Sugiarto, A. Baharudin, D. S. Putra, and N. Hidayat, "The Design And Development Of Voltage Amplifiers Using Microcontroller For Mass Absolute Pressure (MAP) Sensor In The Toyota Avanza," VANOS Journal of Mechanical Engineering Education, vol. 3, no. 2, 2018.

[49] F. Majedi, F. Susanto, A. T. Hardiyanto, and T. Hardiyanto, "Penerapan Sistem Alternating Current Generator (Acg) Pada Motor Bensin mattrix Gasoline Engine Cx200," Jurnal Teknologi Terpadu, vol. 6, no. 1, pp. 77-81, 2018.

[50] E. Tarigan, "Studi Kasus: Karakteristik 
Konsumsi Bahan Bakar Sepeda Motor 110 CC Matic dengan CDI BRT," Automotive Experiences, vol. 1, no. 02, pp. 53-57, 2018.

[51] R. S. Maryati and M. F. Jauhari, "Manual Select Switch Mode Untuk Penanganan Diagnosis Trouble Code Pada Sistem Injeksi Sepeda Motor Suzuki," in Prosiding SNRT (Seminar Nasional Riset Terapan) Politeknik, 2018, no. November, pp. 71-78.

[52] T. Sugiarto, D. S. Putra, W. Purwanto, and W. Wagino, "Analisis Perubahan Output Sensor Terhadap Kerja Aktuator pada Sistem EFI (Electronic Fuel Injection)," INVOTEK: Jurnal Inovasi Vokasional dan Teknologi, vol. 18, no. 2, pp. 91-100, 2018.

[53] Novendra, R. Lapisa, and T. Sugiarto, "Analisis Perbandingan Kekerasan Baja Pada Sproket Depan Dan Belakang Sepeda Motor Supra X 125 Hardening Dengan Menggunakan Media Pendinginan Yang Bervariasi," Automotive Engineering Education Journal, vol. 1, no. 2, 2018.

[54] A. Burhanudin, B. Septian, B. Waluyo, and Saifudin, "Investigasi Kesalahan Pembacaan Display Konsumsi Bahan Bakar Pembacaan Display Konsumsi Bahan Bakar pada Mobil Datsun Go," Automotive Experiences, vol. 1, no. 02, pp. 53-57, 2018.

[55] M. Setiyo, S. Soeparman, S. Wahyudi, and N. Hamidi, "The Alternative Way to Drive the Automobile Air-Conditioning, Improve Performance, and Mitigate the High Temperature: A Literature Overview," Periodica Polytechnica Transportation Engineering, vol. 46, no. 1, pp. 36-41, 2018.

[56] M. Luthfi, D. Ahmad, M. Setiyo, and S. Munahar, "Uji Komposisi Bahan Bakar dan Emisi Pembakaran Pertalite dan Premium," Jurnal Teknologi, vol. 10, no. 1, pp. 67-72, 2018.

[57] Listiyono, "Optimization of Material Variations and Installation Angle Catalytic Converter in Muffler to Emission Gas," Journal of Information Engineering and Applications, vol. 8, no. 2, pp. 13-20, 2018.

[58] A. Kurniawan, Martias, and I. Y. Basri,
"Pengaruh Penggunaan Pulsed Secondary Air Injection System (PAIR) Terhadap Emisi Gas Buang Karbon Monoksida (CO) Dan Hidro Karbon (HC) Pada Sepeda Motor Suzuki Satria F 150 cc," Automotive Engineering Education Journal, vol. 2, no. 1, 2018.

[59] H. Nurrohman, B. Susanto, and N. Widodo, "Studi Eksperimen Variasi Tekanan Bahan Bakar Terhadap Emisi pada Mesin EFI," Automotive Experiences, vol. 1, no. 02, pp. 53-57, 2018.

[60] M. Mardyaningsih and A. Leki, "Kajian Penggunaan Zeolit Alam Kabupaten Kupang Untuk Menurunkan Emisi Gas Buang Co dan HC Pada Motor Bensin 4 Silinder," Jurnal Teknik Mesin, vol. 1, no. 1, pp. 1-10, 2018.

[61] F. Majedi, F. Susanto, B. P. Sandy, and B. Wiratmoko, "Efek Perubahan Kapasitas Mesin dan Penggunaan 2 Busi pada Motor 4 Langkah terhadap BSFC dan Emisi Gas Buang," Jurnal Teknologi Terpadu, vol. 6, no. 2, p. 115-, 2018.

[62] A. Supriyanto, H. Maksum, and D. S. Putra, "Perbandingan Penggunaan Berbagai Jenis Bahan Bakar Terhadap Emisi Gas Buang Pada Sepeda Motor 4 Langkah," Automotive Engineering Education Journal, vol. 1, no. 2, 2018.

[63] M. Muhammad, B. Amin, and T. Sugiarto, "Pengaruh penggunaan katalis plat tembaga pada knalpot sepeda motor terhadap kandungan emisi karbon monoksida (co) dan hidrokarbon (hc)," Automotive Engineering Education Journal, vol. 1, no. 2, 2018.

[64] W. Purwanto, T. Sugiarto, H. Maksum, D. S. Putra, and E. Alwi, "Comparison of Three Topologies Rotor to Improve Efficiency and Torque for High-Speed Spindle Motor Applications," in 2018 International Conference on Applied Information Technology and Innovation (ICAITI, 2018, pp. 176-181.

[65] W. Purwanto, D. S. Putra, and Risfendra, "Effect of Stator Slot Geometry on High Speed Spindle Motor Performance," in 2018 International Conference on Information and Communications Technology (ICOIACT), 2018, pp. 560564. 
[66] D. R. Putra, H. Maksum, and D. S. Putra, "Pengaruh perbandingan penggunaan roller racing dengan roller standard terhadap daya dan torsi pada motor matic," Automotive Engineering Education Journal, vol. 1, no. 2, 2018.

[67] A. Irawan and D. A. Tyagita, "Study Comparative Of Fuel Use Of LPG , Pertalite , And Pertamax On Engine Erformance Armfield Cm $11 \mathrm{Mk}$ II," in The First International Conference of Food and Agriculture, 2018, pp. 554559.

[68] S. K. Utama, Erzeddin Alwi, and Wagino, "Pengaruh variasi coil sistem pengapian suzuki satria fu 150 tahun 2012 terhadap torsi dan daya," Automotive Engineering Education Journal, vol. 1, no. 2, 2018.

[69] Y. R. Fauzi, "Pengaruh Penambahan Turbo Cyclone Aksial Terhadap Aliran Dan Performa Motor Bakar," Turbo : Jurnal Program Studi Teknik Mesin, vol. 7, no. 1, pp. 25-31, 2018.

[70] K. Supriadi, Wagino, and T. Sugiarto, "Pengaruh Variasi Oversize Piston Terhadap Konsumsi Bahan Bakar Yamaha Mio Sporty," Automotive Engineering Education Journal, vol. 1, no. $2,2018$.

[71] A. Robiul and A. Udin, "Test Characteristics of Two-Step Gasoline Engine with Fuel Mix Essential Oils and Aceton," in The First International Conference of Food and Agriculture, 2018, pp. 478-485.

[72] J. Effendi, H. Maksum, and T. Sugiarto, "Analisis Penggunaan Penstabil Tegangan (Voltage Stabilizer)," Automotive Engineering Education Journal, vol. 1, no. 2, 2018.

[73] Nurhadi, "Pengembangan Sepeda Motor Listrik Sebagai Sarana Transportasi Ramah Lingkungan," in Seminar Nasional Inovasi dan Aplikasi Teknologi di Industri 2018, 2018, pp. 249-255.

[74] Arman and A. K. Muhammad, "Rancang Bangun Alat Ukur Emisi Gas Buang Yang Terintegrasi Komputer Untuk Kendaraan Ringan," in Prosiding Seminar Hasil Penelitian (SNP2M) 2018 (pp.232-238), 2018, pp. 232-238.

[75] H. Purwono and Rasma, "Perancangan Perkakas Untuk Melepaskan Dan
Memasang Piston Steering Cylinder Pada Unit HD1500-7," Jurnal Mesin Teknologi, vol. 12, no. 1, pp. 47-53, 2018.

[76] Sudarmadji, B. S. A. Purwono, and Santoso, "Performance Evaluation Criterion of Nanofluid," in Microfluidics and Nanofluidics and, M. S. Kandelousi, Ed. London: IntechOpen, 2018, pp. $277-$ 292.

[77] H. Fahrian, S. Munahar, and D. S. Putra, "PengembanganSirkuit Security System untuk Meningkatkan DriverBehaviour Control padaKendaraan," Automotive Experiences, vol. 1, no. 1, pp. 13-19, 2018.

[78] A. N. Miftachul and B. Waluyo, "Model Sistem Monitoring Minyak Pelumas Digital dengan Memanfaatkan Gaya Apung dengan Sensor Load Cell," Automotive Experiences, vol. 1, no. 02, pp. 53-57, 2018.

[79] G. M. Seprihadaniansyah, A. Kuswoyo, and M. Adriana, "Modifikasi Knalpot Menggunakan Katalitik Konverter Dan Arang Akasia Guna Mengurangi Emisi Gas Buang Kendaraan," Jurnal Elemen, vol. 5, no. 1, pp. 11-19, 2018.

[80] W. N. Farid Majedi, Indarto Yuwono, "Penggunaan Modul Thermoelectric (Elemen Peltier) Pada Sistem Pendingin Bahan Bakar Bensin," Journal of Electrical, Electronics, Control, and Automotive Engineerin, vol. 3, no. 1, 2018.

[81] B. C. Purnomo and B. H. Priyanto, "Kajian Pengaruh Perubahan Konsentrasi Refrigerant Musicool 134CO2 Terhadap Performa Katup Ekspansi Tipe TEV," Automotive Experiences, vol. 1, no. 02, pp. 53-57, 2018.

[82] M. Crawford, "3 Emerging Trends in Automotive Engineering," ASME, 2013. [Online]. Available: https://www.asme.org/engineeringtopics/articles/automotive/3-emergingtrends-automotive-engineering. [Accessed: 25-May-2019].

[83] Omic International, "Emerging Trends in Automotive Engineering," 2019. [Online]. Available: https://www.omicsonline.org/conference s-list/emerging-trends-in-automotiveengineering. [Accessed: 25-May-2019]. 
[84] Argone National Laboratory, "Energy System Division: Areas of Focus." [Online]. Available: https://www.anl.gov/es/areas-of-focus. [Accessed: 25-May-2019]. 